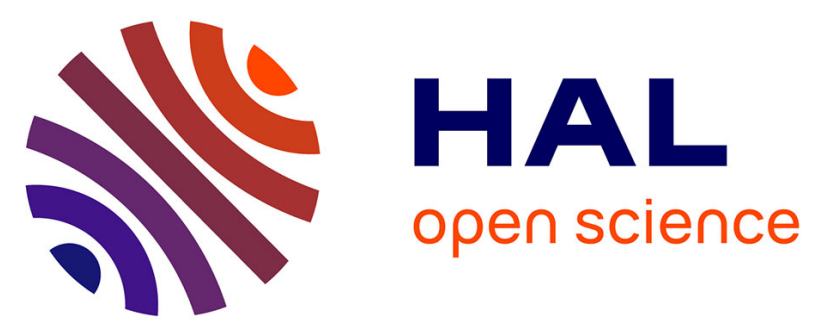

\title{
Quantification of vertical movement of low elevation topography combining a new compilation of global sea-level curves and scattered marine deposits (Armorican Massif, western France)
}

Paul Bessin, François Guillocheau, Cécile Robin, Jean Braun, Hugues Bauer, Jean-Michel Schrötter

\section{To cite this version:}

Paul Bessin, François Guillocheau, Cécile Robin, Jean Braun, Hugues Bauer, et al.. Quantification of vertical movement of low elevation topography combining a new compilation of global sea-level curves and scattered marine deposits (Armorican Massif, western France). Earth and Planetary Science Letters, 2017, 470, pp.25-36. 10.1016/j.epsl.2017.04.018 . insu-01521638

\section{HAL Id: insu-01521638 \\ https://hal-insu.archives-ouvertes.fr/insu-01521638}

Submitted on 30 Dec 2019

HAL is a multi-disciplinary open access archive for the deposit and dissemination of scientific research documents, whether they are published or not. The documents may come from teaching and research institutions in France or abroad, or from public or private research centers.
L'archive ouverte pluridisciplinaire HAL, est destinée au dépôt et à la diffusion de documents scientifiques de niveau recherche, publiés ou non, émanant des établissements d'enseignement et de recherche français ou étrangers, des laboratoires publics ou privés. 
Title: Quantification of vertical movement of low elevation topography combining a new compilation of global sea-level curves and scattered marine deposits (Armorican Massif, western France)

Author names and affiliations:

Paul BESSIN ${ }^{\mathrm{a}}$

a: LPG - Le Mans, UMR 6112, Université du Maine, Avenue Olivier Messiaen, 72085 Le Mans, France

\section{François GUILLOCHEAU ${ }^{b}$}

b: Géosciences Rennes, UMR 6118, Université de Rennes 1, CNRS 263, avenue du Général Leclerc, 35042 Rennes cedex, France

Cécile ROBIN ${ }^{\mathrm{b}}$

b: Géosciences Rennes, UMR 6118, Université de Rennes 1, CNRS 263, avenue du Général Leclerc, 35042 Rennes cedex, France

Jean BRAUN ${ }^{\mathrm{c}}$

c: Helmholtz Centre Potsdam, German Research Center for Geosciences (GFZ), Telegrafenberg, Potsdam, Germany

Hugues BAUER ${ }^{d}$

${ }^{d}$ : BRGM, Centre scientifique et technique, 3 avenue Claude-Guillemin, BP 360009, 45060 Orléans cedex 02, France

Jean-Michel SCHROËTTER ${ }^{\mathrm{e}}$

e: BRGM, Direction régionale Bretagne, Rennes Atalante Beaulieu, 2 rue de Jouanet, 35700 Rennes

Corresponding author:

Paul BESSIN ${ }^{\mathrm{a}}$

a: LPG - Le Mans, UMR 6112, Université du Maine, Avenue Olivier Messiaen, 72085 Le Mans, France email: paul.bessin@univ-lemans.fr 


\section{Highlights}

- A formalized method for quantifying low-amplitude vertical movements

- Re-assessment of the reliability of the published Cenozoic global sea level curves

- A low amplitude subsidence of the Armorican massif quantified from 30 to $3.6 \mathrm{Ma}$

- Cenozoic growth of Apulia-Eurasia convergence effects on Armorican deformations 


\section{Abstract}

2 A wide range of methods are available to quantify Earth's surface vertical movements but most of Pleistocene. cosmogenic isotope studies) vertical movements characteristic of plate interiors. The difference between the present-day elevation of ancient sea-level markers (deduced from well dated marine deposits corrected from their bathymetry of deposition) and a global sea-level curve are sometimes used to estimate these intraplate vertical movements. Here, we formalized this method by reassessing the reliability of published global sea-level curves to build a composite curve that combines the most reliable ones at each stage, based on the potential bias and uncertainties inherent to each curve. We suggest i) that curves which reflect ocean basin volume changes are suitable for the ca. 100 to $35 \mathrm{Ma}$ "greenhouse" period ii) whereas curves that reflects ocean water volume changes are better suited for the ca. 35 to $0 \mathrm{Ma}$ "icehouse" interval and iii) that, for these respective periods, the fit is best when using curves that accounts for both volume changes. We used this composite sealevel curve to investigate the poorly constrained Paleogene to Neogene vertical motions of the Armorican Massif (western France). It is characterized by a low elevation topography, a Variscan basement with numerous well dated Cenozoic marine deposits scattered upon it. Using our method, we identify low amplitude vertical movements ranging from $66 \mathrm{~m}$ of subsidence to $89 \mathrm{~m}$ of uplift over that time period. Their spatial distribution argues for a preferred scale of deformation at medium wavelengths (i.e., order $100 \mathrm{~km}$ ), which we relate to the deformation history of northwestern European lithosphere in three distinct episodes. i) A phase of no deformation between 38 and $34 \mathrm{Ma}$, that has been previously recognized the scale of northwestern Europe, ii) a phase of low subsidence between 30 and $3.6 \mathrm{Ma}$, possibly related to buckling of the lithosphere and iii) a phase of more pronounced uplift between $2.6 \mathrm{Ma}$ and present, which we relate to the acceleration of the Africa-Apulia convergence or to enhanced erosion in the rapidly cooling climate of the

\section{.}


27 Keywords: Quantification of vertical movements; Global sea-level; Intraplate domains; Low 28 amplitude deformation; Armorican Massif; Cenozoic 


\section{Introduction}

30 Characterizing the Earth's surface vertical movements, i.e. its uplift and subsidence, by quantifying

31 their amplitude and wavelength, and deciphering the nature of the processes responsible for these movements remain challenging questions for the geoscientist. These movements often result from lithospheric-scale deformations, which range in scale from short $\left(\times 10^{-6}-\times 10^{1} \mathrm{~km}\right)$ to long wavelengths $\left(\times 10^{3}-\times 10^{5} \mathrm{~km}\right.$; S Sengör, 2009). Plate boundaries, where topography commonly takes the form of narrow mountain belts and rifts, are characterized by short-wavelength deformation processes (e.g. faulting) where the amplitude of deformation often exceeds its wavelength (Bishop, 2011). Conversely, in plate interiors, where topography takes mostly the form of large plateaus surrounded by plains, hills and flat sedimentary basins, medium $\left(x 10^{2} \mathrm{~km}\right)$ to long $\left(x 10^{3} \mathrm{~km}\right)$ wavelength deformation processes dominate, where the amplitude of deformation is two to three orders of magnitude smaller than its wavelength (i.e. $\times 10^{2} \mathrm{~m}$ ). The processes thought to be responsible for medium wavelength deformation are lithospheric buckling, crustal loading or underplating (Watts, 2001; Anell et al., 2009) and, for the longest wavelength deformation, mantledriven processes such as dynamic topography - the vertical deflection of the surface topography (gravitational stresses) required to balance the viscous stresses in the flowing mantle at the base of the lithosphere (Braun, 2010; Molnar et al., 2015).

A wide range of methods, such as low-temperature thermochronology (Apatite Fission Tracks Analysis, for example), cosmogenic isotopes and OSL (Optically Stimulated Luminescence) studies were developed and used to quantify denudation at plate boundaries where uplift leads to substantial erosion and rock cooling. Unfortunately, these methods cannot be readily used in most plate interiors, because the vertical movements and associated denudation are often i) too low to be quantified by thermochronology or ii) too old (> $5 \mathrm{Ma}$ ) to be recorded by cosmogenic isotopes or OSL methods. Consequently, little attention has been paid to the non- or post-orogenic uplift and 53 subsidence of plate interiors, characterized by low elevation plateaus and other small amplitude 54 topographic features. 
Recently, several studies have attempted to estimate the amplitude of vertical movements in continental interiors from the difference between the present-day elevation of dated ancient sealevel markers and their respective initial elevations (e.g. Bétard, 2010; Braga et al., 2003; Dorsey et al., 2011; Pederson et al., 2002; Peulvast and Bétard, 2015). The modern elevations of ancient sealevel markers are deduced from the elevations of well dated marine deposits corrected from their bathymetry at the time of deposition (corrected for sediment load and compaction effects in thick sedimentary series, e.g. Dorsey et al., 2011). The initial elevation of ancient sea-level markers can be inferred from any given global sea-level curve. Such a method is suitable for quantifying low amplitude vertical movements typical of intraplate domains and associated low elevation topography, but its results strongly depend on the assumed global sea-level curve used to infer the past sea-level elevation. This is especially true when the inferred amplitude of deformation is less than 200 meters, because of the large discrepancies that exist between several published sea-level curves (e.g. up to $200 \mathrm{~m}$ between the Haq et al. (1987) and Miller et al. (2005)'s curves during the Upper Cretaceous), which has led many to question their validity (e.g. Moucha et al., 2008; Müller et al., 2008; Miall, 2010).

The main purpose of this study is to improve and formalize this simple method of quantifying the timing and amplitude of vertical movements in low elevation areas where thin marine sedimentary veneers are preserved, by taking into account uncertainties on bathymetry estimates and global sealevel elevation at the time of deposition. As an accurate knowledge of global sea-level changes through times is a cornerstone in this method, we have re-assessed the reliability of many curves

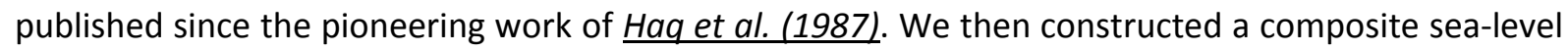
curve by combining the most reliable intervals of several curves, taking into account the potential bias and uncertainties inherent to the methods used to build each curve. We then applied the method to compute improved estimates of uplift and subsidence of the Armorican Massif during the Cenozoic. 
The Armorican Massif is one of numerous Paleozoic (Caledonian and Variscan) basement blocks of

81 western Europe characterised by low to moderate elevation plateaus such as the Massif Central, the Rhenish Massif, the Bohemian Massif or the Scottish Highlands. Most of these basement blocks have experienced several episodes of burial and exhumation in the Mesozoic and/or Cenozoic (i.e. long after their post-orogenic planation; e.g. Barbarand et al., 2013). This is the case for the Armorican Massif (Bessin et al., 2015), that is part of the Variscan Belt (Ballèvre et al., 2009). This low relief and low elevation topographic feature was twice buried then exhumed between Jurassic and Paleocene times in response to relative movements between Iberia and Eurasia. However, as other western European basements, its Paleogene to Neogene uplift/subsidence and deformation history is still poorly constrained (Bessin et al., 2015) despite the presence of numerous well dated Cenozoic shallow marine deposits scattered upon it. The Armorican Massif is therefore an ideal place to use our method and derive from it improved estimates of the timing and amplitude of surface vertical movements. Using these estimates, we discuss the possible driving mechanisms responsible for these uplift/subsidence events in the framework of the recent tectonic history of western Europe.

\section{Calculation of vertical movements: methodology}

\subsection{Principles}

Plate interiors often preserved scattered remnants of marine sediments as thin sedimentary veneers (up to $\times 1 \mathrm{~m}$ to $10-20 \mathrm{~m}$ thick). Their occurrence and preservation are function of three parameters: i) global sea-level changes, ii) surface uplift and subsidence and iii) sedimentary flux that can drive further subsidence (Posamentier et al., 1988). In low preservation environments (e.g. most of western Europe Variscan massifs), this latter driver can be disregarded as sedimentary thicknesses are usually low $(<50 \mathrm{~m})$ and the additional subsidence they can generate by isostasy or compaction is negligible (Allen and Allen, 2013). Areas where no section is missing should be privileged to limit the uncertainty associated with unknown amounts of erosion. In this case, the presence of a marine 
106 sediment can be related to global sea-level changes and surface uplift or subsidence events only.

107 Consequently, the difference between the modern elevation of a marine sediment and an estimate

108 of its initial elevation, i.e. at time of deposition, can be regarded as an accurate estimate of the sum

109 of all vertical movements it recorded until present (finite vertical movement). To compute this

110 vertical movement, one needs to accurately measure:

111 - the age of the marine sediment, which is commonly obtained from its fossiliferous fauna and

112 flora contents (biostratigraphic markers);

113 - the bathymetry under which this sediment was deposited, which is also constrained by its

114 fossiliferous fauna and flora content (palaeo-environmental markers) together with 115 sedimentary facies;

116 - the global sea-level at the time of sediment deposition, which we will obtain from a compilation of reliable global sea-level curves (as discussed in §3.3).

118 The uncertainty on the estimate of vertical movement can also be obtained from uncertainties on

119 estimates of paleo-bathymetry and global sea-level height, together with the uncertainty on the age 120 of the marine deposit.

\subsection{Finite vertical movement calculation}

123 For a given dated marine sedimentary remnant $s_{1}$ deposited in a low preservation environment, the

124 vertical displacement it recorded from its deposition at time $t_{1}$ to present-day $\left(t_{t}\right)$, hereafter called 125 finite vertical movement $(f v m)$, is

$$
f v m_{(1 \rightarrow \mathrm{t})}=z s_{1} t_{t}-z s_{1} t_{1} \quad \text { thus, }
$$

$$
f v m_{(1 \rightarrow \mathrm{t})}=z s_{1} t_{t}-s l_{1}+b_{1}
$$


128 where $z s_{1} t_{t}$ is its present-day elevation, $s l_{1}$ the global sea-level elevation at $t_{1}$ (with respect to 129 present-day global sea-level) and $b_{1}$ the bathymetry under which $s_{1}$ was deposited (Fig.1). For each 130 location, we do not estimate a single value but a range of $f v m_{(1 \rightarrow t)}$ by considering a range of past 131 bathymetric estimates and a range of global sea-level values. The former is related to the uncertainty 132 in bathymetry inherent to using palaeo-environmental markers and sedimentary facies of $s_{1}$. The 133 latter is due to errors in global sea-level (amplitude) which have to incorporate the uncertainties in

134 the ages of the marine deposits (timing). Theses ranges of bathymetry and global sea-level lead to 135 estimates of $f v m$ minimum $\left(f v m_{(1 \rightarrow t) \min }\right)$, mean $\left(f v m_{(1 \rightarrow t) \text { mean }}\right)$ and maximum $\left(f v m_{(1 \rightarrow t) \max }\right)$ 136 values, which are obtained from (uplift case)

140 where $s l_{1 \min }$ and $b_{1 \min }$ are the minimum values of sea-level and bathymetry at $t_{1}$, respectively,

$141 s l_{1 \max }$ and $b_{1 \max }$ correspond to the maximum value of sea-level and bathymetry at $t_{1}$, respectively,

142 and $s l_{1 \text { mean }}$ is the mean value of global sea-level at $t_{1}$ (Fig.1). These fvm computations were 143 performed using several global sea-level curves currently available (e.g. Haq et al., 1987; Miller et al., 144 2005; Kominz et al., 2008; Müller et al., 2008; Rowley, 2013) in order to define a range of possible 145 sea-levels for any given time in the past and thus the related range of fvm values (Fig.1).

\subsection{Quantification of successive vertical movements through times and surface elevation restoration}

148 Each fvm quantified may integrate or "stack" several phases of uplift and subsidence which can be 149 dissociated in some places. Indeed, some topographic surfaces, such as basement flats or lows, may 150 have recorded several marine flooding events through time and low preservation marine deposits of 151 different ages can therefore be preserved on these surfaces. As a consequence, if two remnants $s_{1}$ 
152 and $s_{2}$ deposited at $t_{1}$ and $t_{2}\left(t_{1}\right.$ being older than $\left.t_{2}\right)$, respectively, are found close to one another

153 upon a same topographic surface (and in the absence of faulting or subsequent erosion), they both

154 underwent the same fvm from $t_{2}$ to present-day $\left(t_{t}\right), f v m_{(2 \rightarrow \mathrm{t})}$, implying that the fvm recorded by $s_{1}$

155 from $t_{1}$ to $t_{2}$ is

156

$$
f v m_{(1 \rightarrow 2)}=f v m_{(1 \rightarrow \mathrm{t})}-f v m_{(2 \rightarrow \mathrm{t})}
$$

157 Moreover, $z s_{1} t_{2}$ the elevation of $s_{1}$ (i.e. of the flooded topographic surface) at $t_{2}$ can be restored

158 from the equations (1) and (6):

$$
z s_{1} t_{2}=\left(f v m_{(1 \rightarrow \mathrm{t})}-f v m_{(2 \rightarrow \mathrm{t})}\right)+z s_{1} t_{1} \quad \text { thus, }
$$

$$
z s_{1} t_{2}=z s_{1} t_{t}-f v m_{(2 \rightarrow \mathrm{t})}
$$

161 Its range are computed from $f v m_{(2 \rightarrow \mathrm{t})}$ uncertainties, and therefore derived from the equations (3), (4) and (5):

163

$$
z s_{1} t_{2 \min }=z s_{1} t_{t}-f v m_{(2 \rightarrow \mathrm{t}) \min }
$$

(subsidence: $z s_{1} t_{2} \max$ )

164

$$
z S_{1} t_{2 \text { mean }}=z s_{1} t_{t}-f v m_{(2 \rightarrow \mathrm{t}) \text { mean }}
$$

$$
z S_{1} t_{2} \max =z s_{1} t_{t}-f v m_{(2 \rightarrow \mathrm{t}) \max }
$$

(subsidence: $z s_{1} t_{2} \min$ )

166 where $z S_{1} t_{2}$ min' $^{\prime} z S_{1} t_{2}$ mean and $z S_{1} t_{2}$ max are the minimum, the mean and the maximum elevation of $s_{1}$ at $t_{2}$, respectively. These computations were applied to a dataset from the Armorican Massif, using several global sea-level curves as discussed hereafter (see §3.3) in order to restore ranges of successive elevations of several topographic surfaces, and constrain the amplitude and rate of their vertical movement through times. 
175 Several short-term $\left(10^{0}-10^{4} \mathrm{yr}\right)$ to long-term $\left(10^{6}-10^{9} \mathrm{yr}\right)$ processes may lead to global sea-level

176 fluctuations through times by changing i) ocean water volume or ii) ocean basin volume (Miller et al.,

177 2005; Miller et al., 2011; Conrad, 2013).

178 Ocean water volume changes are mainly due to short-term $\left(10^{1}-10^{4} \mathrm{yr}\right.$, e.g. Milankovitch cycles)

179 processes, chiefly ice sheet volume variations (up to $200 \mathrm{~m}$ of amplitude) between "icehouse" and

180 "greenhouse" periods and ocean water thermal contraction or dilatation which together define

181 climato-eustasy (Miller et al., 2011; Conrad, 2013). Such fluctuations trends can be sustained for

182 several million years due to long-term climate change trends. Lower amplitude $(\approx 5-10 \mathrm{~m}$

183 amplitude) changes in ocean water volume can also be induced by variations in continental water

184 storage (lakes and groundwater) and desiccation or flooding of marginal sea (Miller et al., 2011). On

185 longer time scales $\left(10^{9} \mathrm{yr}\right)$, variations in global water distribution between the Earth's surface and the

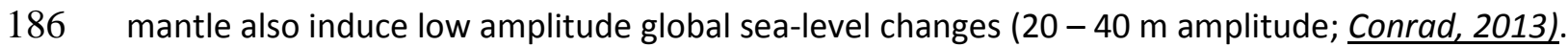

187 Ocean basin volume changes are mainly related to long-term driving factors $\left(10^{6}-10^{8} \mathrm{yr}\right)$ and are

188 chiefly induced by mid-ocean ridge volume variations (amplitude: 100-300 m), through variations in

189 oceanic crust production and ridge length (Müller et al., 2008; Miller et al., 2011; Conrad, 2013)

190 related to mantle convection and the dispersal and assembly of continents (Conrad, 2013). To a

191 lesser degree, seafloor loading changes due to oceanic plateaus emplacement and removal or

192 terrigeneous sedimentary flux fluctuations can affect global sea-level (with amplitudes up to ca. 60

$193 \mathrm{~m}$; Miller et al., 2005). On longer time scales, dynamic topography can induce extremely slow (up to 1

$194 \mathrm{~m} \cdot \mathrm{Ma}^{-1}$ ) global sea-level changes of relatively high amplitudes (up to $200 \mathrm{~m}$; Spasojevic and Gurnis,

195 2012). On shorter time scales $\left(10^{3}-10^{5} \mathrm{yr}\right)$, Glacial Isostatic Adjustment (GIA or postglacial rebound)

196 also induces global sea-level changes (< $5 \mathrm{~m}$ amplitude since $120 \mathrm{kyr}$; Conrad, 2013; Miller et al.,

197 2011; Pedoja et al., 2011) but these can be neglected when considering global sea-level changes on

198 longer time scales (> 1 Ma; Miller et al., 2011). 
201 Since the end of the 1970's, numerous and often conflicting global sea-level curves have been 202 published, based on different assumptions and datasets, for Mesozoic to Cenozoic times. They are 203 built using five main methods, including (data available in Supplementary Material S1 and plotted in 204 S2):

(1) Coastal onlap analysis based on the recognition and measurement of coastal onlap constrained by correlations of stratigraphic sequences using boreholes, outcrops and seismic data. This method was used by Haq et al., $(1987$; global dataset) and Haq and Al-Qahtani (2005; Arabian platform regional dataset).

(2) Continental flooding estimates based on using global hypsometric estimates combined with estimates of continental flooding through time derived from paleogeographic datasets. This method was used by Rowley (2013), using data from four global paleogeographic datasets (Scotese and Golonka, 1992; Smith et al., 1994; Markwick, 2011; Blakey, 2012).

(3) Backstripping based on estimating the effects of sediment compaction, sediment loading and water-depth changes on sedimentary records at high biochronostratigraphic resolution located in presumably stable areas such as continental passive margins. These sea-level datasets mainly come from the eastern US margin (Miller et al., 2005; Kominz et al., 2008).

(4) A method based on ocean floor age-area and depth-area distributions where ocean basin volume changes are obtained from the distribution of ocean floor area with age and a relationship between age and bathymetric depth, derived from global geodynamic models. This method was used by Müller et al. (2008) and Spasojevic and Gurnis (2012). 
(5) Oxygen isotopes $\left(\delta^{18} O\right)$ proxies based on $\delta^{18} \mathrm{O} / \delta^{16} \mathrm{O}$ ratio measurements of marine carbonates (foraminifera) which provide indirect records of ice-volume and temperature changes since Late Neogene (ca. 9 Ma) times. This method was used by Miller et al. (2011).

Backstripped curves were later corrected for the assumed effect of dynamic topography as published by Müller et al. (2008) from the Miller et al. (2005) dataset and by Kominz et al. (2008). sea-level values (including uncertainties) were computed for each geologic time scale stage since the Upper Cretaceous and at the dating resolution of studied marine sedimentary remnants (Supplementary Material S1; Fig.2).

\subsection{Reliability and selection of compiled global sea-level curves}

233 Our compilation of global sea-level curves shows large discrepancies between the available curves (of 234 ca. 100 to 200 meters for some stage; Fig.2). For our calculations, we constructed a composite global 235 sea-level curve (and associated uncertainty) by using different curves at different times, based on the 236 nature of the data that was used to construct it and how reliable that data is for each time period 237 considered (Fig.3; Supplementary Material S1).

238 Haq et al. (1987) and Haq and Al-Qahtani (2005) global sea-level curves based on coastal onlap 239 measurements were discarded because of i) the lack of complete dataset publication, ii) the 240 overestimation of sea-level amplitude due to insufficient correction for compaction, loading and 241 tectonic subsidence and iii) the chronostratigraphic imprecision of correlated sequence boundaries 242 (see Miall, 2010 for a review).

243 The latest curves from the backstripping method (Miller et al., 2005; Kominz et al., 2008) were 244 selected for the "icehouse" times since ca. $35 \mathrm{Ma}$ (Eocene-Oligocene transition) and the onset of 
permanent Antarctic ice-sheet (Zachos et al., 2008). These curves are reliable for this period as they

246 reflect well global sea-level changes driven by ocean water volume variations (Miller et al., 2011).

247 They were however excluded for the preceding periods (pre-35 Ma) as the backstripping method

248 used requires data from stable sedimentary basins and it is well known now that the eastern US

249 margin used for constraining Miller et al. (2005) and Kominz et al. (2008)'s curves underwent

250 dynamic topography due to North America's overriding upon the Farallon plate slab (Kominz et al.,

251 2008; Moucha et al., 2008; Müller et al., 2008). Further back in time, the resulting global sea-level

252 amplitudes are consequently downward shifted by about $50 \mathrm{~m}$ with respect to continental flooding

253 studies (Miller et al., 2011). The backstripped curves corrected from dynamic topography were

254 discarded as they require for Eocene times either i) an unrecognised deformation event of the

255 aastern US margin (Kominz et al., 2008) or ii) an unrealistically high global sea-level which requires

256 melting of an ice-sheet volume three times higher than the present-day one (Rowley, 2013). For

257 Pliocene times, the curve from Miller et al. (2011) based on oxygen isotope proxies of ice-volume

258 changes was selected as it reflects ocean water volume variations, which mainly drives Pliocene sea-

259 level changes (Miller et al., 2011).

260 The global sea-level curve of Müller et al. (2008) was selected for the "greenhouse" times before ca.

$26135 \mathrm{Ma}$ (Zachos et al., 2008). This method is however discarded for estimates of global sea-level

262 changes since ca. 35 Ma because ocean water volume changes, which became the main driving-

263 factor of global sea-level changes ("icehouse" period; Miller et al., 2011), are not considered (Müller

264 et al., 2008). The Spasojevic and Gurnis (2012) curve was not selected because sea-level amplitudes

265 match the overestimated ones of the Haq et al. (1987) and Haq and Al-Qahtani (2005) curves for the

266 pre-35 Ma times (Fig.2).

267 The global sea-level curve of Rowley (2013), based on global hypsometry and global paleogeographic

268 maps was selected for the entire period (i.e. since Upper Cretaceous) as it encompasses the effects

269 of both ocean water and ocean basin volume changes on sea-level (Rowley, 2013). The use of global 
data (paleogeography and hypsometry) lowers the influence of not having a stable reference for

271 global sea-level measurements and removes local and regional effects (as the integral of dynamic 272 topography over the Earth's surface must be zero, assuming a constant radius for the Earth; Rowley, 273 2013). The dispersion of estimates from each paleogeographic datasets used (Scotese and Golonka, 274 1992; Smith et al., 1994; Markwick, 2011; Blakey, 2012) is responsible for the uncertainty on the resulting global sea-level curve ( $\pm 50 \mathrm{~m}$ for 100 to $60 \mathrm{Ma}$ and $\pm 20 \mathrm{~m}$ for 60 to $0 \mathrm{Ma}$ (Rowley, 2013)).

276 It is worth pointing out that i) from c.a. 100 to $35 \mathrm{Ma}$, Müller et al. (2008)'s curve which reflects 277 ocean basin volume changes and ii) from c.a. 35 to $0 \mathrm{Ma}$, (Miller et al., 2005) and (Kominz et al., 278 2008)'s curves which reflect ocean water volume changes, both agree for these respective periods with Rowley (2013)'s curve which integrates the effects of both driving factors.

\section{Application to the example of the Armorican Massif for Cenozoic times}

\subsection{Regional setting and available data}

284 The Armorican Massif, located in western France, is a basement that was strongly deformed from 285 late Devonian to Carboniferous times as a part of the Variscan belt similar to many other western 286 European massifs (e.g. Massif Central, Rhenish Massif, Ardennes Massif; Ballèvre et al., 2009). This 287 basement is surrounded by three major sedimentary basins that started subsiding during Mesozoic 288 times: i) the Western Approaches Basin to the north, ii) the starved South Armorican Margin to the 289 west and south and iii) the intracratonic Paris Basin to the east (Fig.4).

290 Like many other western European Variscan domains, the Armorican Massif corresponds today to a 291 region of low topographic elevation ranging from $150 \mathrm{~m}$ to $200 \mathrm{~m}$ (highest peaks: $417 \mathrm{~m}$ ). Its present292 day topography is made of three main upland plateaus or highs of elevation above $200 \mathrm{~m}$ : the 293 Western Brittany Plateau to the west, the Vendée High to the South and the Lower Normandy 294 Plateau to the North (Fig.5). These uplands plateaus are connected by low elevation plateaus 
295 (ranging from $30 \mathrm{~m}$ to $100 \mathrm{~m}$ ) such as the Eastern Brittany Low (Fig.5; Bessin et al., 2015). This

296 collection of low relief plateaus is inherited from six stepped planation surfaces which have been

297 dated using the marine sedimentary remnants scattered over them. Their analysis reveals that the

298 Armorican Massif was (partly?) buried and exhumed twice in response to western European 299 intraplate deformation events (Bessin et al., 2015):

(1) A first burial event of the massif beneath marine sediments took place at a time of overall subsidence across western Europe, i.e. during Jurassic times;

(2) The first exhumation event occurred during the early Cretaceous at the time of initiation and break-up of the rift between Iberia and Eurasia;

(3) A second burial episode of the massif beneath chalk deposits took place during a second overall western European subsidence phase in the Late Cretaceous;

(4) A second exhumation episode occurred during latest Cretaceous to early Eocene times, resulting from differential uplift of the Armorican Massif induced by the convergence between the African and Eurasian plates.

The maximum depth of burial during each subsidence episode is thought to be low $(<500 \mathrm{~m})$ as indicated by the small amount of coeval siliciclastic sediments in the surrounding basins.

311 Previous sedimentological and geomorphological studies (Bonnet et al., 2000; Brault et al., 2004)

312 found that the Armorican Massif low elevation topography was later incised during two successive 313 episodes of river network development in response to the convergence between African and 314 Eurasian plates. The first drainage network developed during Late Miocene times and the resulting 315 valleys were later filled by Piacenzian to Gelasian marine (but also continental) deposits (Brault et al., 316 2004). The present-day river network developed around the early to middle Pleistocene boundary. 317 Up to $90 \mathrm{~m}$ of Pleistocene uplift has been estimated from measurements of the resulting incision 318 (Bonnet et al., 2000). 
However, no constraint is currently available regarding vertical movements that may have affected the Armorican Massif between early Eocene and Late Miocene times. Our purpose here is to quantify surface vertical movements over that period and identifying the processes that may have caused them.

323 The data we will use for this come from marine sedimentary remnants deposited during the main

324 Cenozoic marine flooding events of the massif (exhaustive reference list regarding dataset is 325 provided in Supplementary Material S1). Marine sediments were dated using i) biostratigraphic data 326 (benthic and pelagic foraminifera, ostracoda, charophytes, macrofauna, pollens, spores and 327 dinocysts; see Guillocheau et al., 2003 for a review) and ii) Electron Spin Resonance data for Pliocene 328 times (see Van Vliet-Lanoë et al., 2002 for a review). Respective bathymetric estimates at the time of 329 marine sediment deposition were obtained from both paleo-ecological (fossiliferous fauna and flora) 330 and sedimentological data (see Guillocheau et al., 2003 for a review). Four separate depositional 331 environment types were defined:

(1) Brackish environments with water depth ranging from ca. 0 to $5 \mathrm{~m}$;

(2) Foreshore environments with water depth ranging between sea-level at mean high tide and

(3) Shoreface environments with water depth ranging between sea-level at mean low-tide and

(4) Upper offshore (open marine) shelf environments with water depth ranging between fairDeposits corresponding to six marine flooding events during Cenozoic times are preserved on the 341 Armorican Massif (Guillocheau et al., 2003). They correspond to a series of relative sea-level high 342 stand during (1) the Ypresian (early Eocene; ca. 56-48 Ma), (2) the Bartonian (late Eocene; 41.0-38.0 
$343 \mathrm{Ma}$ ), (3) the Rupelian (early Oligocene; 33.9-28.1 Ma), (4) the Langhian-Serravallian (middle Miocene;

344 16.0-11.6 Ma), (5) the uppermost Miocene (Messinian?; 7.3-5.3 Ma) and the Piacenzian (early 345 Pleistocene; 3.6-2.6 Ma). Bartonian, Rupelian, Langhian-Serravallian and Piacenzian marine 346 sediments were used for quantifying vertical movement as they match the following requirements: i) 347 they are accurately dated (resolution around or lower than that of a Stage on the chronostratigraphic 348 chart), ii) they are well distributed upon the massif and iii) their bathymetry at the time of deposition 349 is well constrained. The Ypresian flooding, which was restricted along the South Armorican Margin 350 (Guillocheau et al., 2003), and the Messinian flooding, which is exposed on too few outcrops (Brault 351 et al., 2004), were not selected.

352 Almost all of these deposits correspond to a thin veneer of sediments over pre-existing topography, 353 that must relate to marine flooding with little to no contribution from compaction or isostatic 354 subsidence by sediment loading. However, some of the Bartonian to Rupelian deposits are preserved 355 in small narrow grabens bounded by N150E faults (e.g. 2 to $4 \mathrm{~km}$ width for $400 \mathrm{~m}$ depth for the 356 largest one, the Rennes Basin; Fig.4; Bauer et al., 2016). Because we focus here on estimating 357 medium to long wavelength surface subsidence, these short wavelength deformation gradients were 358 restored by assuming that the present-day elevation of the top of these basins can be used as a 359 proxy for the elevation of the sediments at the time of their deposition.

\subsection{Vertical movement of the Armorican Massif}

\subsubsection{Finite vertical movements}

364 fvm calculations were performed for each global sea-level dataset available and for each timespan 365 for which data match requirements for fvm computation (data available and plotted on 366 Supplementary Material S1 and S3, respectively). Hereafter, we only present computations from the 367 global sea-level curves that we selected for each time interval (see §3.2). The fvm values listed in the 
368 text correspond to the mean fvm values computed (minimum and maximum values are plotted on 369 Fig.6).

370 The fvm calculations point to an overall subsidence of the Armorican Massif from 41.0-38.0 Ma 371 (Bartonian) to present-day, except in the Northern (Trégor area) and Eastern regions (Fyé Basin; 372 Fig.6; uplift of ca. $50 \mathrm{~m}$ ). This subsidence is of long wavelength and its magnitude ranges from i) 373131.4 to $-20.4 \mathrm{~m}$ using the Müller et al. (2008) global sea-level data to ii) -95.4 to $15.6 \mathrm{~m}$ using the 374 Rowley (2013) global sea-level data. Both indicate a low differential subsidence (of ca. $100 \mathrm{~m}$ ) 375 between present-day offshore and onshore domains. This Armorican-scale differential subsidence 376 characterized a deformation process with a wavelength of ca. $300 \mathrm{~km}$, i.e. a medium wavelength 377 deformation.

Since 33.9-28.1 Ma (Rupelian), the fvm values suggest an overall uplift with a differential component 379 between the central (Eastern Brittany Low, Léon Platform) and the northern parts (Western 380 Approaches Basin and Carentan Flats) of the massif (Fig.6). The magnitude of this uplift ranges from i) 38133.8 to $97.0 \mathrm{~m}$ using the Kominz et al. (2008) global sea-level data to ii) 39.0 and $109.4 \mathrm{~m}$ using the 382 Rowley (2013) global sea-level data for the central part of the massif. Uplift is lower in the western 383 part of the massif with values of $25.1 \mathrm{~m}$ using the Kominz et al. (2008) global sea-level data and 21.7 384 m using the Rowley (2013) global sea-level data. Conversely, the northernmost part of the studied 385 area (Western Approaches and Carentan Flats) exhibits stronger subsidence with a magnitude of i) $38678.2 \mathrm{~m}$ using the Kominz et al. (2008) global sea-level data and ii) 73.0 using the Rowley (2013) global 387 sea-level data. These values may be underestimated because the Western Approaches Basin 388 sediment thickness estimates were not decompacted. At a regional scale, these estimates suggest a 389 doming of the Armorican massif with up to ca. $180 \mathrm{~m}$ (175.2 m and $182.4 \mathrm{~m}$ respectively using the 390 Kominz et al. (2008) and the Rowley (2013) global sea-level data) of differential vertical movement 391 between the dome apex and its edges. 
392 A finite uplift is evidenced by our fvm computations (Fig.6) since 16.0-11.6 Ma (Langhian393 Serravallian). Highest uplift magnitudes are located i) north of the central part of the Armorican 394 Massif (North East of the Eastern Brittany Low) with up to $127.0 \mathrm{~m}$ to $130.7 \mathrm{~m}$ of uplift respectively 395 computed using the Kominz et al. (2008) and the Rowley (2013) global sea-level data and ii) in a 396 lesser degree, south of the central part of the Massif (East of Vendée Low) with magnitudes up to $397117.5 \mathrm{~m}$ from the (Kominz et al., 2008) global sea-level data and $121.2 \mathrm{~m}$ from the (Rowley, 2013) 398 global sea-level data. Lower values are found to the north of the massif (Carentan Flats), to the west 399 of the central part of the massif (West of the Eastern Brittany Low) and to the south of the massif

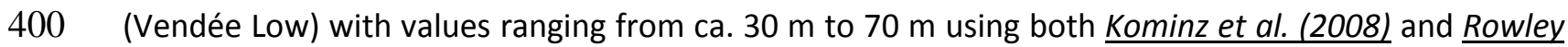
$401 \quad$ (2013) global sea-level data.

402

403

404

405

406

407

408

409

Since 3.6-2.6 Ma (Piacenzian), an overall uplift of the Armorican Massif is suggested by the computed fvm values (Fig.6, S1). Higher magnitudes are located west of the Eastern Brittany Low and north of the southern branch of the SASZ, with up to $153,4 \mathrm{~m}$ according to the Miller et al. (2011) global sealevel data and $141.0 \mathrm{~m}$ when using the Rowley (2013) global sea-level data. Lower magnitudes of uplift ranging from ca. $55 \mathrm{~m}$ (Eastern Brittany Low) to ca. $70 \mathrm{~m}$ (northwestern and southwestern part of the massif) are found according to both Miller et al. (2011) and Rowley (2013) global sea-level data. Conversely, the northern part of the massif (Carentan Flats) is the only area of predicted subsidence since Piacenzian times, with subsidence values of ca. $25 \mathrm{~m}$ to $40 \mathrm{~m}$ using the Rowley (2013) and the Miller et al. (2011) global sea-level data, respectively.

\subsubsection{Intra-Cenozoic vertical movements}

Three areas of the Armorican Massif contain well dated marine sediments of different ages (Bartonian, Rupelian, Langhian-Serravalian, Gelasian) that are close to each other and unaffected by faulting or post-depositional erosion. These are the Carentan Flat (in its northern part), the Eastern Brittany Low (in its central part) and the Vendée Low (in its southern part; Fig.5, Fig.7). Using the fvm 
417 values computed above, the intra-Cenozoic vertical movement recorded by these domains were

418 estimated using global sea-level curves as discussed above, i.e. Müller et al. (2008) and Rowley (2013)

419 until Bartonian times, Miller et al. (2005), Kominz et al. (2008) and Rowley (2013) for Rupelian to

420 Miocene times and Miller et al. (2011) and Rowley (2013) since Pliocene times. Finally, the successive

421 elevations of the topographic surfaces at Bartonian, Rupelian, Langhian-Serravalian and Gelasian

422 times were restored for each sea-level curve (data available in Supplementary Material S4). The

423 amplitude of the vertical movements are low and three main results are obtained (values hereafter

424 listed are means of estimated vertical movement from selected global sea-level curves calculations

425 plotted on Fig.7):

426 - From 38 to $34 \mathrm{Ma}$ (Priabonian), a phase of low subsidence is suggested for the northern 427 (Carentan Flats) and southern (Vendée Low) parts of the massif. Values range between 7.5 428 and $15.2 \mathrm{~m}$ of subsidence over that period (i.e. a subsidence rate of 1.3 to $2.1 \mathrm{~m} \mathrm{Ma}^{-1}$ ). The 429 38-34 Ma times are at the transition between the Müller et al. (2008)'s curve and the 430 backstripped curves (Miller et al., 2005; Kominz et al., 2008) suitable periods which may 431 introduce some bias. As no significant vertical movement is evidenced from the Rowley 432 (2013)'s data (Fig.7), a phase of stability is therefore privileged. The central part of the massif 433 (Eastern Brittany Low) underwent $65.9 \mathrm{~m}$ of subsidence, possibly overestimated due to fault 434 gradients restoration.

435 - From 30 to 3.6 Ma (Rupelian to Pliocene times), the three domains record subsidence, which 436 we infer as evidence for subsidence of the entire Armorican Massif. Between 30 and $16 \mathrm{Ma}$ 437 (Rupelian to Langian-Serravallian times), vertical movement values ranges between $8.0 \mathrm{~m}$ of 438 uplift (possibly overestimated due to fault gradients restoration) and $41.9 \mathrm{~m}$ (or rates of 0.4 $\mathrm{m} \mathrm{Ma}^{-1}$ of uplift to $2.2 \mathrm{~m} \mathrm{Ma}^{-1}$ of subsidence). From 12 to $3.6 \mathrm{Ma}$ (Serravallian to Piacenzian times), subsidence values range from $11.0 \mathrm{~m}$ (or a subsidence rate of $1.0 \mathrm{~m} \mathrm{Ma}^{-1}$ ) in the 

in its northern part (Carentan Flats).

- During the last 2.6 Ma (Piacenzian time to present), a late phase of uplift of the northern (Carentan Flats) and central (Eastern Brittany Low) parts of the massif is inferred with uplift values ranging from 48 to $89 \mathrm{~m}$ (or uplift rates of 15.5 to $28.8 \mathrm{~m} \mathrm{Ma}^{-1}$ ). No data is available for the southern part of the massif (Vendée Low) but $38 \mathrm{~m}$ of uplift can be inferred over the past $12 \mathrm{Ma}$ (Serravalian to present) which corresponds to an uplift rate of $2.7 \mathrm{~m} \mathrm{Ma}^{-1}$.

\section{Armorican Cenozoic vertical movements within the Western European tectonic framework}

From the uppermost Cretaceous to the early Cenozoic, the Armorican Massif is exhumed in response to medium wavelength $\left(\times 10^{2} \mathrm{~km}\right)$ uplift which affected the overall NW European platform and marked the end of deposition and the deformation of the Upper Cretaceous chalk platform (Ziegler, 1990; Anell et al., 2009).

During Bartonian times (41 - $38 \mathrm{Ma})$, homogeneous sedimentary facies preserved on the massif and in surrounding basins (Bauer et al., 2016) point out to a nearly flat and low Armorican topography, suggesting a phase of no deformation, which extended through to Priabonian times (ca. $34 \mathrm{Ma}$ ) as evidenced by our vertical movement estimates. This Bartonian to Priabonian phase ( $41-34 \mathrm{Ma})$ is coeval with the period of no deformation that affected most of north-western Europe during Eocene

460 times, except for offshore Britain and the northern North Sea, which experienced anomalous 461 subsidence possibly related to the development of the Iceland thermal anomaly (see Anell et al., $462 \underline{2009}$ for a review).

463 The Rupelian to Piacenzian (30 - 3.6 Ma) phase of slow subsidence of the Armorican Massif 464 evidenced by our computations (Fig.7) is likely to be related to the growth of numerous small 465 sedimentary basins during Oligocene to middle Miocene times (ca. $35-10 \mathrm{Ma}$ ) along the western 
466 side of the British Isles (Cornwall, Wales, northern Ireland and the Hebrides Sea; Walsh, 1999) in a 467 largely strike-slip regime, which led to local basin inversions (Williams et al., 2005). This low 468 subsidence phase of the massif is also coeval with Oligocene (Eocene?) to Miocene short-wavelength 469 deformation observed in surrounding basins and on the northwestern European platform (Anell et 470 al., 2009) that includes i) strike-slip to compressive folding along the South Armorican Margin 471 (Guillocheau et al., 2003), ii) major basin inversion (e.g. up to $700 \mathrm{~m}$ of reverse fault movement) in 472 the Western Approaches Basin (Le Roy et al., 2011) and iii) NNE-SSW striking left-lateral 473 transtensional wrenching of the European Cenozoic Rift System (Bourgeois et al., 2007), all of which 474 are taught to be related to reactivation of pre-existing structures by in-plane stresses (e.q. Anell et 475 al., 2009). Reactivation of these structures are superimposed on a medium wavelength deformation 476 that initiated around $35 \mathrm{Ma}$ and is thought to be related to lithospheric mantle buckling in response 477 to the Apulia-Eurasia collision (Handy et al., 2010; Cloetingh et al., 2015). The paroxysm of this 478 buckling is thought to have taken place around $17 \mathrm{Ma}$ (Burdigalian) with the development of folds at 479 a wavelength of ca. 225-275 km (Bonnet et al., 2000; Bourgeois et al., 2007). Evidence for this 480 buckling includes uplift of the Bohemian Massif and the Vosges-Black Forest Arch and amplification 481 of uplift of the Massif Central that initiated at the Oligocene-Miocene transition in response to 482 thermal thinning of the lithosphere. Conversely, we propose here that the Armorican Massif is 483 possibly located on a lithospheric-scale syncline which induced the subsidence of the massif from 484 Rupelian to Piacenzian times (Fig.6 and Fig.7), i.e. from 30 to $3.6 \mathrm{Ma}$.

485 The Pleistocene uplift (2.6 - $0 \mathrm{Ma}$; of ca. 50 to $90 \mathrm{~m}$; Fig.6) that we evidence is consistent with 486 previous geomorphic studies of the Armorican Massif (Bonnet et al., 2000; Brault et al., 2004) which 487 preclude a GIA origin from geomorphic data (Bonnet et al., 2000). This recent uplift is also observed 488 in western Europe, e.g. in the Paris Basin (Antoine et al., 2007), the Ardennes Massif or the Rhenish 489 Shield (Demoulin and Hallot, 2009). It is commonly thought to be related to either an enhanced convergence rate of the Apulia-Eurasia collision at the early-middle Pleistocene transition or a 
491 climate-induced increase in erosion rate that led to topographic unloading and a change in stress

492 regime (Cloetingh et al., 2015; Herman and Champagnac, 2016).

\section{6. Conclusion}

495

496 (1) We formalized a method to quantify low amplitude vertical movements which are difficult to document using low-temperature thermochronology, OSL dating or cosmogenic isotope methods. Our method is based on estimating the difference the present-day elevation of well dated marine sediments (corrected from their bathymetry of deposition) and selected global sea-level reconstructions at the time of sediment deposition.

501 (2) We compiled available global sea-level curves and re-assess their reliability to build a composite one. Considering the various processes that may have caused global sea-level changes through time, we are able to disregard some of the global sea-level curves because of a clear bias they introduce or because the method used to construct them is inapplicable for the time period considered. We concluded that the Müller et al (2008) 's curve is suitable for the ca. 100 to 35 Ma "greenhouse" period while the Miller et al. (2005) and the Kominz et al. (2008)'s curves better reflect global sealevel changes during the ca. 35 to $0 \mathrm{Ma}$ "icehouse" period. We also note that both agree with Rowley

508 (2013)'s curve in their respective period of optimum reliability.

509 (3) Based on our estimates of amplitude, wavelength and timing of the patterns of uplift/subsidence 510 affecting the Armorican Massif, we suggest that lithospheric buckling related to the Apulia-Eurasia 511 convergence is responsible for the medium-wavelength deformation we identify. More precisely, the 512 Armorican Massif underwent i) a phase of tectonic quiescence characterizing most of NW Europe 513 during Bartonian to Priabonian times ( $38-34 \mathrm{Ma}$ ) followed by ii) a phase of low subsidence during 514 Rupelian to Piacenzian times $(30-3.6 \mathrm{Ma})$ possibly due to the position of the massif within a 515 downing limb of a lithospheric scale buckling instability driven by the Apulia-Eurasia convergence and 
516 iii), most recently, a Pleistocene (2.6-0 Ma) phase of uplift related to either the intensification of the

517 Africa-Apulia convergence or a climate-induced erosional enhancement of this long-term uplift.

518

519 Acknowledgments

520 We acknowledge the Région Bretagne (grant ARED2011-14000177) for funding Paul Bessin's Ph.D.

521 thesis and the BRGM for providing additional data and funding. We thank T. Lelandais (Université du

522 Maine) for resampling some of the sea-level curve data. We are grateful to an anonymous reviewer

523 for helpful comments that improved our manuscript. 
Allen, P.A., Allen, J.R., 2013. Basin analysis: Principles and application to petroleum play assessment. $3^{\text {rd }}$ edition.Wiley-Blackwell, Oxford, United Kingdom, $619 \mathrm{p}$.

Anell, I., Thybo, H., Artemieva, I.M., 2009. Cenozoic uplift and subsidence in the North Atlantic region: Geological evidence revisited. Tectonophysics, 474, 78-105.

Antoine, P., Limondin Lozouet, N., Chaussé, C., Lautridou, J.-P., Pastre, J.-F., Auguste, P., Bahain, J.J., Falguères, C., Galehb, B., 2007. Pleistocene fluvial terraces from northern France (Seine, Yonne, Somme): synthesis, and new results from interglacial deposits. Quaternary Science Reviews, 26, 2701-2723.

Ballèvre, M., Bosse, V., Ducassou, C., Pitra, P., 2009. Palaeozoic history of the Armorican Massif: Models for the tectonic evolution of the suture zones. Comptes Rendus Geoscience, 341(23), 174-201.

Barbarand, J., Quesnel, F., Pagel, M., 2013. Lower Paleogene denudation of Upper Cretaceous cover of the Morvan Massif and southeastern Paris Basin (France) revealed by AFT thermochronology and constrained by stratigraphy and paleosurfaces. Tectonophysics, 608 , 1310-1327.

Bauer, H., Saint-Marc, P., Bessin, P., Chateauneuf, J.J., Bourdillon, C., Wyns, R., Guillocheau, F., 2016. New insights on the Cenozoic history of the Armorican Massif: contribution of the CDB1 deep borehole (Rennes Basin, France). Comptes Rendus Geoscience, 348, 387-397.

Bessin, P., Guillocheau, F., Robin, C., Schroëtter, J.-M., Bauer, H., 2015. The Armorican Massif (Western France): a two times exhumed relief shaped by planation surfaces in response to Iberia-Eurasia relative movements. Geomorphology, 233, 75-91.

Bétard, F., 2010. Uplift and denudation history at low-elevation passive margins: Insights from morphostratigraphic analysis in the SE Armorican Massif along the French Atlantic margin. Comptes Rendus Geoscience, 342, 215-222.

Bishop, P., 2011. Landscape Evolution and Tectonics. In: K.J. Gregory, A.S. Goudie (Eds.), The SAGE handbook of Geomorphology. SAGE Publications, London, UK, pp. 489-512.

Blakey, R., 2012. Rectangular global maps. http://cpgeosystems.com/rect globe.html

Bonnet, S., Guillocheau, F., Brun, J.-P., Van Den Driessche, J., 2000. Large-scale relief development related to Quaternary tectonic uplift of a Proterozoic-Paleozoic basement; the Armorican Massif, NW France. Journal of Geophysical Research: Solid Earth, 105, 19273-19288.

Bourgeois, O., Ford, M., Diraison, M., Veslud, C.L.C.d., Gerbault, M., Pik, R., Ruby, N., Bonnet, S., 2007. Separation of rifting and lithospheric folding signatures in the NW-Alpine foreland. International Journal of Earth Sciences, 96, 1003-1031.

Braga, J.C., Martín, J.M., Quesada, C., 2003. Patterns and average rates of late Neogene-Recent uplift of the Betic Cordillera, SE Spain. Geomorphology 50, 3-26.

Brault, N., Bourquin, S., Guillocheau, F., Dabard, M.P., Bonnet, S., Courville, P., Estéoule-Choux, J., Stepanoff, F., 2004. Mio-Pliocene to Pleistocene paleotopographic evolution of Brittany (France) from a sequence stratigraphic analysis; relative influence of tectonics and climate. Sedimentary Geology, 163, 175-210.

Braun, J., 2010. The many surface expressions of mantle dynamics. Nature Geoscience, 3, 825-833.

Cloetingh, S., Ziegler, P.A., Beekman, F., Burov, E.B., Garcia-Castellanos, D., Matenco, L., 2015. 6.12 - Tectonic Models for the Evolution of Sedimentary Basins A2 - Schubert, Gerald, Treatise on Geophysics (2nd Edition). Elsevier, Oxford, UK, pp. 513-592.

Conrad, C.P., 2013. The solid Earth's influence on sea level. Geological Society of America Bulletin, 125, 1027-1052.

Demoulin, A., Hallot, E., 2009. Shape and amount of the Quaternary uplift of the western Rhenish shield and the Ardennes (western Europe). Tectonophysics, 47, 696-708.

Dorsey, R.J., Housen, B.A., Janecke, S.U., Fanning, C.M., Spears, A.L.F., 2011. Stratigraphic record of basin development within the San Andreas fault system: Late Cenozoic Fish Creek-Vallecito basin, southern California. Geol. Soc. Am. Bull. 123, 771 LP-793. 
Guillocheau, F., Brault, N., Thomas, E., Barbarand, J., Bonnet, S., Bourquin, S., Estéoule-Choux, J., Guennoc, P., Menier, D., Neraudeau, D., Proust, J.-N., Wyns, R., 2003. Histoire géologique du Massif armoricain depuis $140 \mathrm{Ma}$ (Crétace-Actuel). Bulletin d'Information des Géologues du Bassin de Paris, 40, 13-28.

Handy, M.R., M. Schmid, S., Bousquet, R., Kissling, E., Bernoulli, D., 2010. Reconciling plate-tectonic reconstructions of Alpine Tethys with the geological-geophysical record of spreading and subduction in the Alps. Earth-Science Reviews, 102, 121-158.

Haq, B.U., Al-Qahtani, A.M., 2005. Phanerozoic cycles of sea-level change on the Arabian Platform. Geoarabia, 10, 127-160.

Haq, B.U., Hardenbol, J., Vail, P.R., 1987. Chronology of fluctuating sea levels since the Triassic. Science, 235, 1156-1167.

Harrison, C.G.A., 1990. Long-term eustasy and epeirogeny in continents. In: R. Revelle (Ed.), Sea-level Change. National Academy Press, Washington, D.C., United, States, pp. 141-160.

Herman, F., Champagnac, J.-D., 2016. Plio-Pleistocene increase of erosion rates in mountain belts in response to climate change. Terra Nova, 28, 2-10.

Kominz, M.A., Browning, J.V., Miller, K.G., Sugarman, P.J., Mizintseva, S., Scotese, C.R., 2008. Late Cretaceous to Miocene sea-level estimates from the New Jersey and Delaware coastal plain coreholes: an error analysis. Basin Research, 20, 211-226.

Le Roy, P., Gracia-Garay, C., Guennoc, P., Bourillet, J.-F., Reynaud, J.-Y., Thinon, I., Kervevan, P., Paquet, F., Menier, D., Bulois, C., 2011. Cenozoic tectonics of the Western Approaches Channel basins and its control of local drainage systems. Bulletin de la Société Géologique de France, 182, 451-463.

Markwick, P., 2011. Paul's palaeo pages. http://www.palaeogeography.net

Miall, A.D., 2010. The geology of stratigraphic sequences. $2^{\text {nd }}$ edition. Springer, Heidelberg and Berlin, Germany, $522 \mathrm{p}$.

Miller, K.G., 2013. Global sea level record. Compilation avalaible at K. G. Miller's webpage: http://geology.rutgers.edu/people/faculty/19-people/faculty/242-kenneth-g-miller.

Miller, K.G., Kominz, M.A., Browning, J.V., Wright, J.D., Mountain, G.S., Katz, M.E., Sugarman, P.J., Cramer, B.S., Christie-Blick, N., Pekar, S., 2005. The Phanerozoic Record of Global Sea-Level Change. Science, 310, 1293-1298.

Miller, K.G., Mountain, G.S., Wright, J.D., Browning, J.V., 2011. A 180-million-year record of sea level and ice volume variations from continental margin and deep-sea isotopic records. Oceanography, 24, 40-53.

Molnar, P., England, P.C., Jones, C.H., 2015. Mantle dynamics, isostasy, and the support of high terrain. Journal of Geophysical Research: Solid Earth, 120, $2014 J$ J011724.

Moucha, R., Forte, A.M., Mitrovica, J.X., 2008. Dynamic topography and long-term sea level variations: There is no such thing as a stable continental platform. Earth and Planetary Science Letters, 271, 101-108.

Müller, R.D., Sdrolias, M., Gaina, C., Steinberger, B., Heine, C., 2008. Long-Term Sea-Level Fluctuations Driven by Ocean Basin Dynamics. Science, 319, 1357-1362.

Pederson, J.L., Mackley, R.D., Eddleman, J.L., 2002. Colorado Plateau uplift and erosion evaluated using GIS. GSA TODAY 12, 4-10.

Pedoja, K., Husson, L., Regard, V., Cobbold, P.R., Ostanciaux, E., Johnson, M.E., Kershaw, S., Saillard, M., Martinod, J., Furgerot, L., Weill, P., Delcaillau, B., 2011. Relative sea-level fall since the last interglacial stage: Are coasts uplifting worldwide? Earth-Science Rev. 108, 1-15.

Peulvast, J.-P., Bétard, F., 2015. A history of basin inversion, scarp retreat and shallow denudation: The Araripe basin as a keystone for understanding long-term landscape evolution in NE Brazil. Geomorphology, 233, 20-40.

Posamentier, H.W., Jervey, M.T., Vail, P.R., 1988. Eustatic control on clastic deposition I.-Conceptual framework. In: C.K. Wilgus, C.G. Hastings, C.G. Kendall, H.W. Posamentier, J.C. Ross, J.C. Van Wagoner (Eds.), Sea-level change, an integrated approach. SEPM (Society for Sedimentary 

States, pp. 125-154.

Rowley, D.B., 2013. Sea Level: Earth's Dominant Elevation-Implications for Duration and Magnitudes of Sea Level Variations. The Journal of Geology, 121, 445-454.

Scotese, C.R., Golonka, J., 1992. Paleogegraphic atlas. Department of Geology, University of Texas, Texas, United States.

Şengör, A.M.C., 2009. The large-wavelength deformations of the lithosphere: Materials for a history of the evolution of thought from the earliest times to plate tectonics. Geological Society of America Memoirs, 196, 1-2.

Smith, A.G., Smith, D.G., Funnell, B.M., 1994. Atlas of Mesozoic and Cenozoic coastlines. Cambridge University Press, Cambridge, United Kingdom, $99 \mathrm{p}$.

Spasojevic, S., Gurnis, M., 2012. Sea level and vertical motion of continents from dynamic earth models since the Late Cretaceous. AAPG Bulletin, 96, 2037-2064.

Van Vliet-Lanoë, B., Vandenberghe, N., Laurent, M., Laignel, B., Lauriat-Rage, A., Louwye, S., Mansy, J.-L., Mercier, D., Hallegouët, B., Laga, P., Laquement, F., Meilliez, F., Michel, Y., Moguedet, G., Vidier, J.-P., 2002. Paleogeographic evolution of northwestern Europe during Upper Cenozoic. Geodiversitas, 24, 511-541

Walsh, P.T., 1999. Pre-Pleistocene geomorphological evolution of West Cornwall. Field Guide Quaternary Research Association, 1999 (West Cornwall), 10-26.

Watts, A.B., 2001. Isostasy and flexure of the lithosphere. University of Cambridge : Cambridge, United Kingdom, $480 \mathrm{p}$.

Williams, G.A., Turner, J.P., Holford, S.P., 2005. Inversion and exhumation of the St. George's Channel basin, offshore Wales, UK. Journal of the Geological Society, 162, 97-110.

Zachos, J.C., Dickens, G.R., Zeebe, R.E., 2008. An early Cenozoic perspective on greenhouse warming and carbon-cycle dynamics. Nature, 451, 279-283.

Ziegler, P.A., 1990. Geological atlas of Western and Central Europe, 1. Shell Internationale Petroleum Maatschappij B.V, The Hague, Netherlands, pp. 239. 
656 Fig.1: Sketch illustrating our finite vertical movement quantification methodology based on i) the 657 bathymetry of deposition and present-day elevation of well dated marine sediments versus ii) 658 elevation of coeval global sea-level.

659 Fig.2: Compilation of global sea-level curves since the Upper Cretaceous; vertical bars indicate the 660 range of acceptable sea-level elevations for each curve and stage.

661 Fig.3: Global sea-level curves since Upper Cretaceous times selected for their suitability in 662 representing reliable proxy of global sea-level (see text for the details of the selection procedure).

663 Fig.4: Synthetic geological map of the Armorican Massif and Mesozoic to Cenozoic surrounding 664 basins. Note the Cenozoic marine transgressions on the massif and the Eocene-Oligocene basins 665 scattered around the massif (data from 1:1.000.000 Geological Map of France (Chantraine et al., 666 2003); Projection: RGF Lambert 1993). NASZ is North Armorican Shear Zone and SASZ is South 667 Armorican Shear Zone.

668 Fig.5: Location map of marine sedimentary deposits used to quantify Cenozoic vertical movements of 669 the Armorican Massif. Black lines: faults from 1:1.000.000 Geological Map of France (Chantraine et 670 al., 2003; Projection: RGF Lambert 1993). White lines: Border of Basement outcrops. Red line: 671 present-day coastline. Fy. : Fyé Basin, Tr.: Trégor Platform, C.F.: Carentan Flat, W.B.P.: Western 672 Brittany Plateau, E.B.L.: Eastern Brittany Low, V.L.: Vendée Low.

673 Fig.6: Map illustrating computed finite vertical movement based on selected curves for global sea674 level change, i.e. Müller et al. (2008) and Rowley (2013) for the Bartonian, Kominz et al. (2008) and 675 Rowley (2013) for the Rupelian, Kominz et al. (2008) and Rowley (2013) for the Langhian-Serravallian 676 and Miller et al. (2011) and Rowley (2013) for the Piacenzian-Gelasian Rupelian. Black lines: faults 677 from 1:1.000.000 Geological Map of France (Chantraine et al., 2003; Projection: RGF Lambert 1993). 678 White lines: Border of Basement outcrops. Red line: present-day coastline.

679 Fig.7: Predicted Cenozoic vertical movement and restored elevations for three Armorican lows, 680 namely the Carentan Flats and the Eastern Brittany and Vendée Lows. 


\section{Supplementary material:}

682 S1: Dataset (.xlsx file) used for i) our compilation of global sea-level curves and ii) quantify finite 683 vertical movements of the Armorican Massif since Cenozoic times.

684 S2: Plot of global sea-level curves discussed in this study. Minimum, maximum and mean values were 685 computed and plotted for each curve and each stage.

686 S3: Geographical plots of finite vertical movement (fvm) estimated for the Armorican Massif for each 687 available curve.

688 S4: Dataset (.xslx file) of vertical movement and restored elevations through Cenozoic times for three 689 Armorican lows, namely the Carentan Flats and the Eastern Brittany and Vendée Lows. 
GUIFEVERTICAL MOVEMENT (low sedimentary preservation)

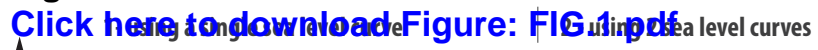

$z$

$\frac{2}{2}$
$\frac{2}{2}$
$\frac{2}{2}$

current elevation

of $s l_{7}$ reffered to

current elevation

of $t_{7}$ sediments

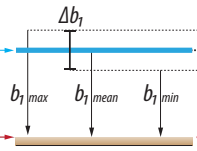

current elevation

of sediments $\left(2 s_{1 t_{t}}\right)$

sea level at $t_{7}\left(s l_{7}\right)$

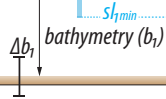

sediments

elevation at $t_{7}\left(z s_{1 t_{1}}\right)$

$$
\frac{\text { present-day }}{\text { sea level }\left(s l_{t}\right)}
$$

$t_{1}$

(time of deposition) (present-day)

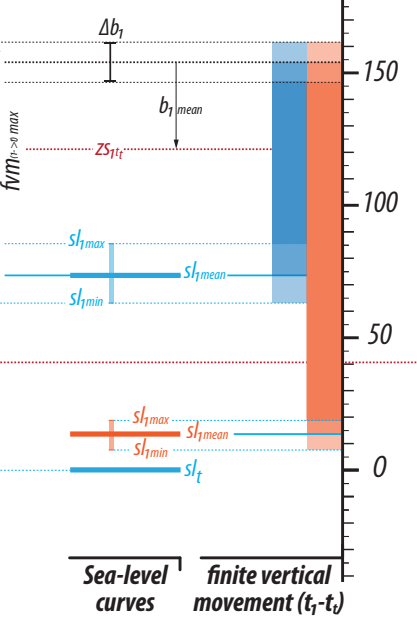

Sea-level and paleo-elevation data curve 1 Curve 2

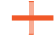

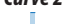
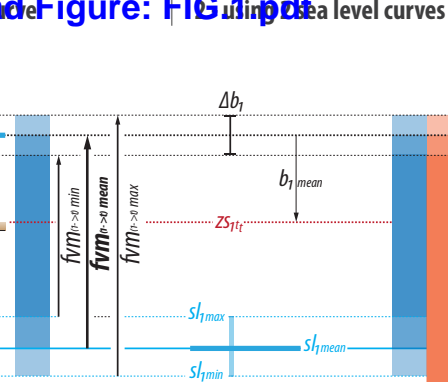

elevation

(m)
Finite vertical movement (fvm) curve 1

Curve 2 
Click here to download Figure: FIG.3.pdf

\section{Backstripping method:}

I Miller et al., 2005 (b.w.i.l.; recalibrated by Miller, 2012 on GTS12)

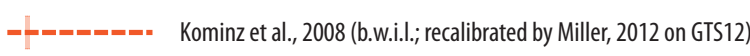

Range of mean sea-level deduced from data of Miller et al., 2005 and Kominz et al., 2008

\section{Continental flooding estimation from}

palaeogeographic reconstructions:

Rowley, 2013(after Scotese and Golonka, 1992; Smith et al., 1994; Markwick, 2011; Blakey, 2012)

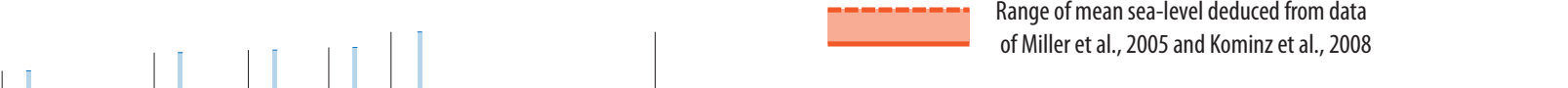

Ocean floor age-area and depth-area distribution reconstruction
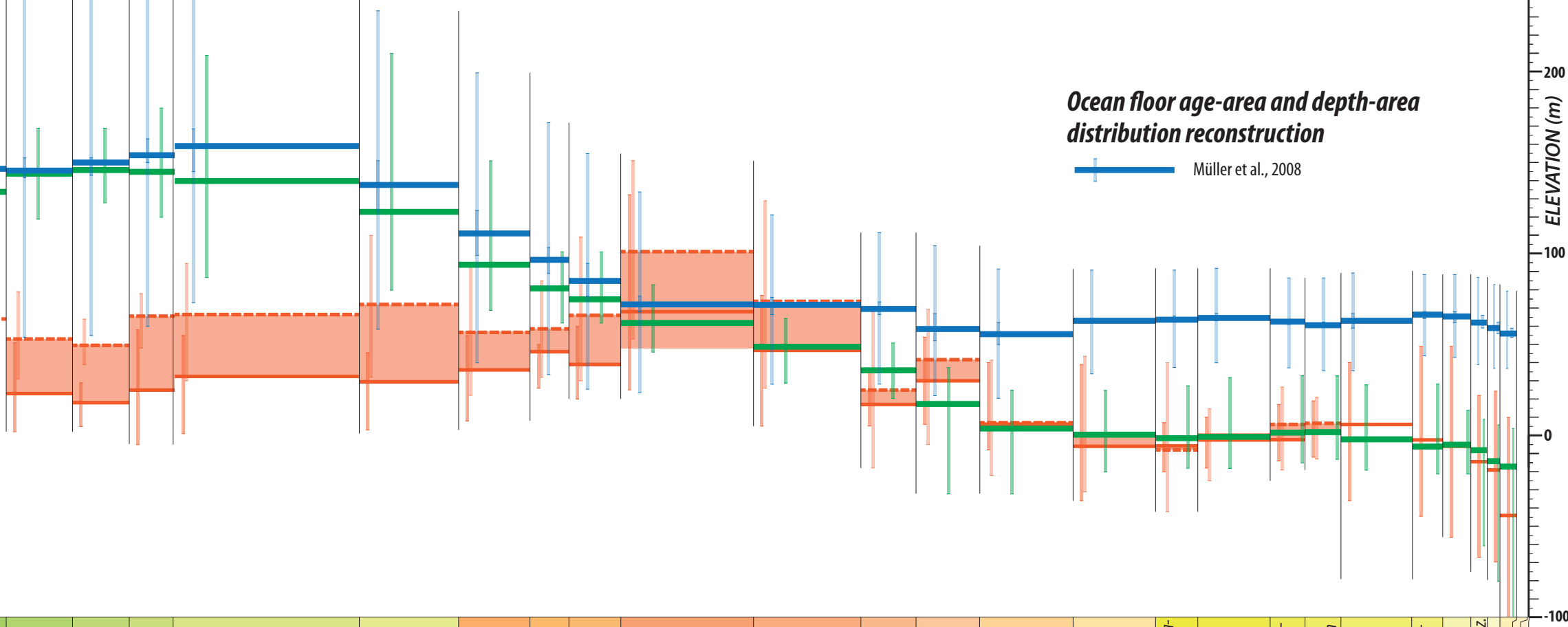

\begin{tabular}{|c|c|c|c|c|c|c|c|c|c|c|c|c|c|c|c|c|c|c|}
\hline Cenomanian & Turonian & $\begin{array}{l}\text { Conia- } \\
\text { cian }\end{array}$ & $\begin{array}{c}\text { Santo- } \\
\text { nian }\end{array}$ & Campanian & Maastrichtian & Danian & $\begin{array}{c}\text { Selan- } \\
\text { dian }\end{array}$ & $\begin{array}{l}\text { Thane- } \\
\text { tian }\end{array}$ & Ypresian & Lutetian & $\begin{array}{c}\text { Barto- } \\
\text { nian }\end{array}$ & $\begin{array}{c}\text { Priabo- } \\
\text { nian }\end{array}$ & Rupelian & Chattian & 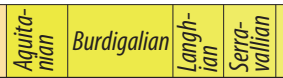 & Tortonian & 촌혼 & \\
\hline \multicolumn{6}{|c|}{ Upper } & \multicolumn{3}{|c|}{ Paleocene } & \multicolumn{4}{|c|}{ Eocene } & \multicolumn{2}{|c|}{ Oligocene } & \multicolumn{2}{|l|}{ Miocene } & Plio. & 裘 H. \\
\hline \multicolumn{6}{|c|}{ CRETACEOUS } & \multicolumn{9}{|c|}{ PALEOGENE } & \multicolumn{2}{|c|}{ NEOGENE } & & Q. \\
\hline
\end{tabular}




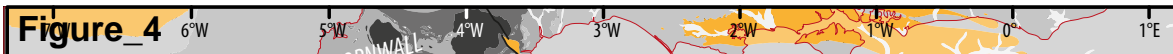
Click here to download Figture.FIG.4.pdf 搃

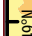

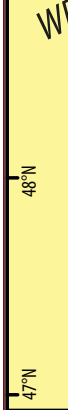

$\sum_{\substack{* \\-4}}^{2}$

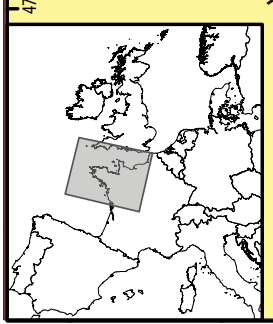

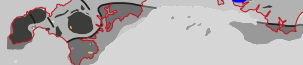

ERN APP

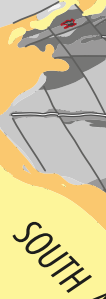

$4^{\circ} \mathrm{W}$

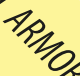<smiles>CO[AsH3]</smiles>

ENGLLSH CHANNEL MASSIR 1 I PARIS
BASIN

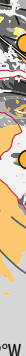

$3^{\circ} \mathrm{W}$

$2^{\circ} \mathrm{W}$
VARISCAN BASEMENT

Plutonic rocks granites, etc.

Metamorphic rocks micaschists, gneiss, etc.

Volcanic rocks basalts, etc.

Sedimentary rocks schists, sandstones, etc.

SURROUNDING BASINS Mesozoic series

Paleogene series Eocene-Oligocene onshore basins Neogene series

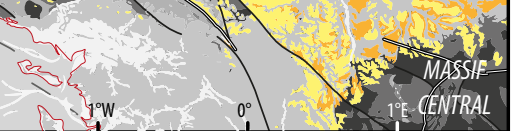

Quaternary

\section{STRUCTURES}

main fault

SASZ: South Armorican Shear Zone NASZ: North Armorican Shear Zone

- minor fault

hidden fault

\section{COASTLINE}

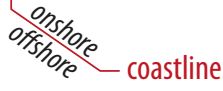




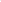




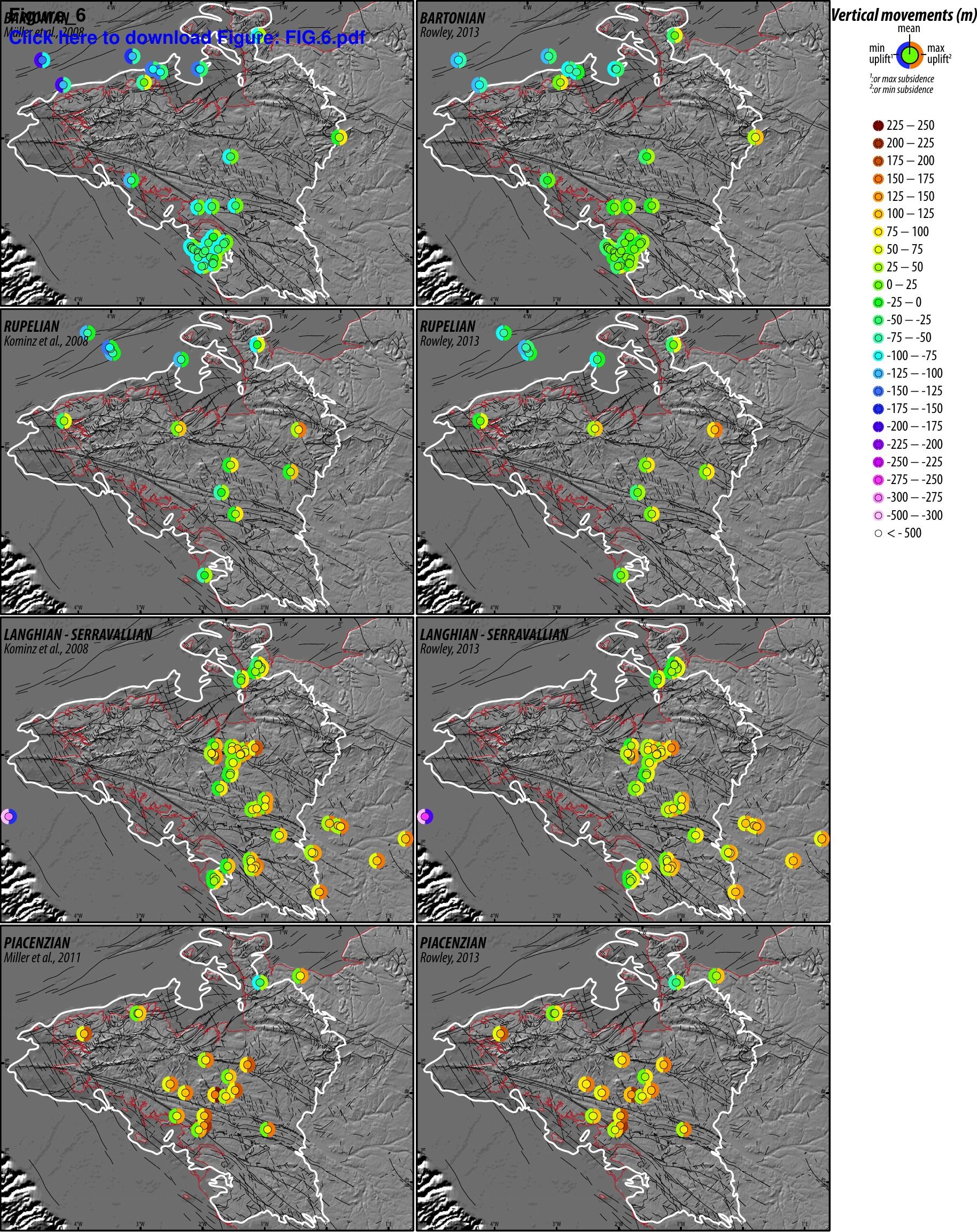




\section{Figure_7}

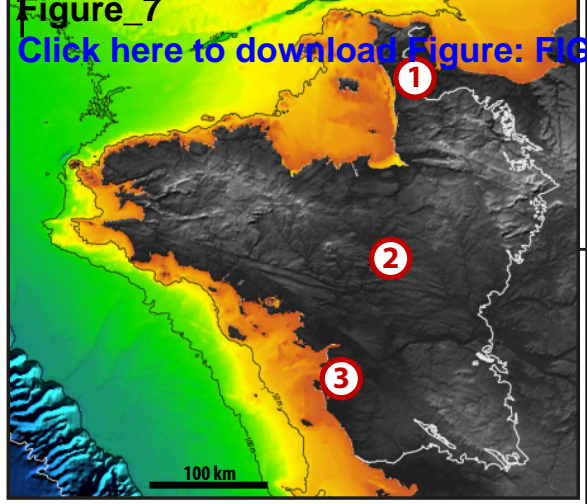

\section{Location}

\section{(1) Carentan Flats}

\section{(2) Eastern Brittany Low \\ (3) Vendée Low}

\section{Successive elevation of the topographic surfaces calculated from fvm calculation based on:}

Deep-sea benthic foraminifera $\delta^{18} 0$ proxy (only for Pliocene times):

Miller et al., 2011

\section{Backstripping method:}

Miller et al., 2005

(recalibrated by Miller, 2013 on GTS12)

Kominz et al., 2008

(recalibrated by Miller, 2013 on GTS12)

Ocean floor age-area and depth-area distribution reconstruction:

- Müller et al., 2008

Continental flooding estimation from

palaeogeographic reconstructions:

I Rowley, 2013

\section{Intra-Cenozoic vertical movements}

mean max Intra-Cenozoic range of vertical movement deduced from restored successive paleo-elevations of the Bartonian marine sediments

-53.5
$(-27:-80)$ Amplitude $(\mathrm{m})$ of vertical movement:

-3.7
$(-1.9-5.5)$$\quad$ Rates $\left(\mathrm{m} \mathrm{Ma}^{-1}\right) \quad \begin{gathered}\text { mean } \\ \text { (highest value }- \text {-lowest value) }\end{gathered}$

* Present-day elevations of the topographic surfaces
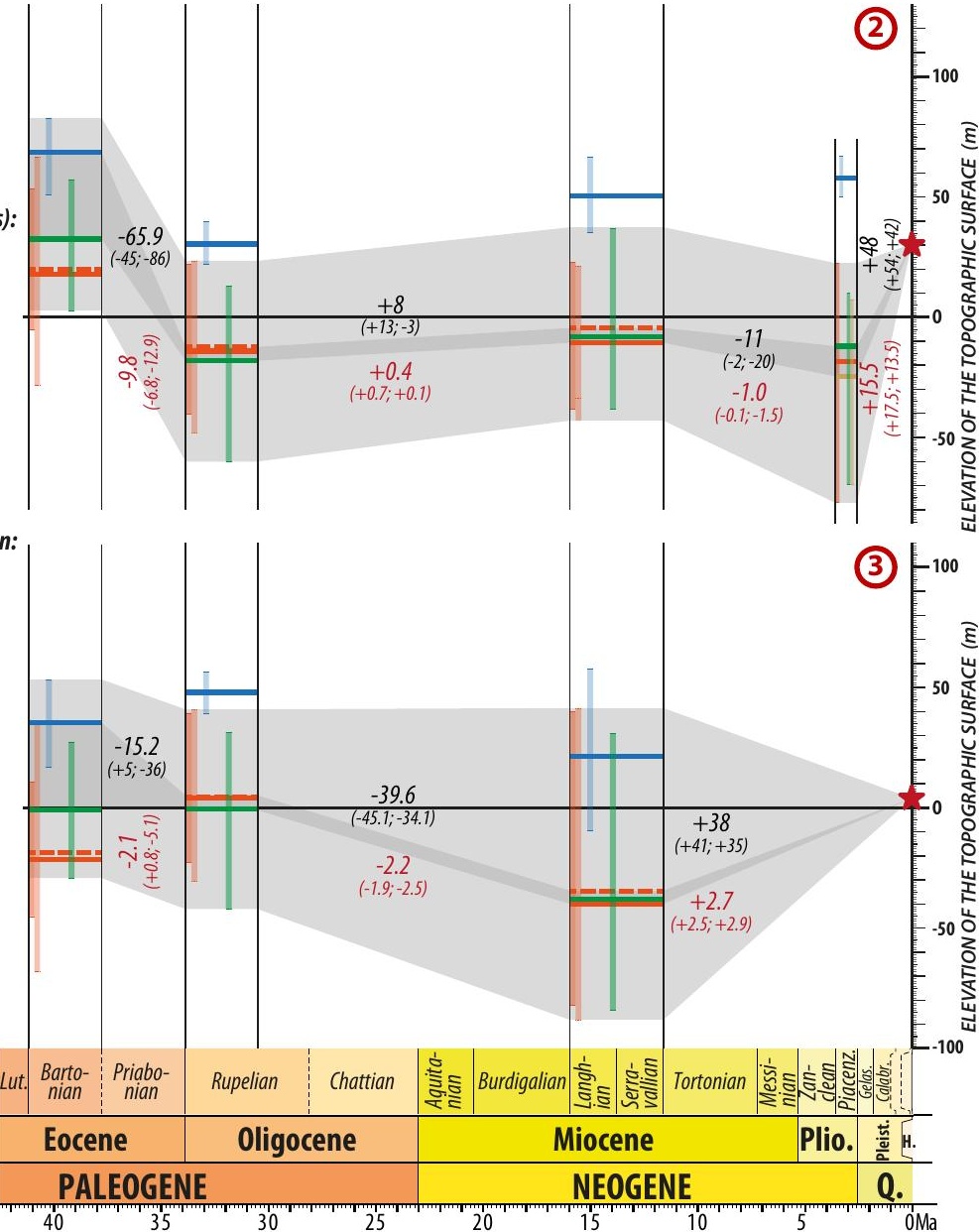